\title{
Developing Digital Module for Human Literacy and Technology Literacy
}

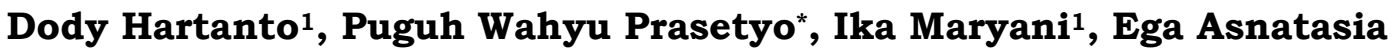 \\ Maharani2 ${ }^{2}$, Intan Puspitasari' ${ }^{1}$, Diah Asta Putri' ${ }^{1}$, Oktira Roki Aji ${ }^{1}$, Wachid \\ Eko Purwanto ${ }^{1}$ \\ ${ }^{1}$ Universitas Ahmad Dahlan, Bantul, Yogyakarta, Indonesia \\ 2International Islamic University Malaysia, Malaysia \\ *Corresponding e-mail: puguh.prasetyo@pmat.uad.ac.id
}

\begin{abstract}
In the era of industry revolution 4.0, many human activities depend on the gadget and the internet connection. We can observe the daily activities of human life right now. When they wake up in the morning, they usually start by using their hand phone or gadget. This condition motivates educators to build a digital module in order to use the positive point of view of the Industry Revolution 4.0 era. In this chance, the researchers develop two topics which are very important for human life in Industry Revolution 4.0, that are, human literacy and technology literacy. Both of the topics were derived into two courses. The course of development of students (Perkembangan Peserta Didik) will be representing the human literacy topics and the course of introduction to Biotechnology (Pengantar Bioteknologi) will be representing the technology literacy topic. The research is a research and development. Furthermore, the products of this research are flipbooks which are uploaded on the Learning Management System managed by Universitas Ahmad Dahlan.
\end{abstract}

Keywords: Development of Students, Digital Module, Human Literacy, Introduction of Biotechnology, Industry Revolution 4.0, Learning Management System, Literacy Skills Technology Literacy.

How to cite: Hartanto, D., Prasetyo, W.P., Maryani, I., Maharani, A. E., Puspitasari, I., Putri, A. I., Aji, R. O., \& Purwanto, E. P. (2020). Developing Digital Module for Human Literacy and Technology Literacy. International Journal on Education Insight, 1(1), 2940. DOI: http://dx.doi.org/10.12928/ijei.v1i1.2086

\section{INTRODUCTION}

The development of science and technology has ushered the world in the era of the industrial revolution 4.0. An era dominated by cyber systems, big data, artificial intelligence, robotic technology and so on (M. M. Gunal, 2019; M. M. Gunal \& M. Karatas, 2019; A. Berg, E. F. Buffie \& L.-F. Zanna, 2019). As a result of this development some of the existing profession slowly began to disappear. This phenomenon became known as the disruptive innovation phenomenon. To deal with this phenomenon, teaching in universities is also required to change. Including the demands of changes in the process of dissemination of lecture material for future generations.

In the field of education, the Industrial Revolution 4.0 was marked by the use of digital technology in the learning process. Utilization of digital technology is known as the cyber system (cyber system). This cyber system is able to make the learning process take place simultaneously without being limited by space and time. This will facilitate the transfer of knowledge from instructors to students. The International Symposium on Open, Distance and E-Learning 2018 (ISODEL) held in Bali on 3-5 December 2018 provided 
dozens of conclusions and recommendations. The conclusions produced include; 1) learning strategies and techniques must focus on students, utilize digital technology, and use innovative approaches; 2) Both parties, teachers and students must be digital/ information literate, technology literate, including involving the role of the community, and parents in universal education. Based on this statement, it is necessary to strive for learning with a cyber system.

The main challenges in learning with a cyber system is to produce human resources who have the ability, namely 1) critical thinking (critical thinking) and problem solving (problem solving); 2) communication and collaborative skills (communication and collaborative skills); 3) creative and innovative thinking skills (creativity and innovative skills); 4) information and communication technology literacy; 5) contextual learning skills; 6) information and media literacy.

The skills acquired through these courses are very important for students to face the changes resulting from the industrial revolution. To make it easier for students to access these courses, it is very much needed the learning process carried out through the Indonesian Open and Integrated Online Learning System (Sistem Pembelajaran Dalam Jaringan or simply SPADA) in the form of digital modules.

\section{RESEARCH METHOD}

The development method refers to the research and development (RnD) model according to the Plomp model. The stages of development include: the needs analysis phase, the design phase, the realization phase (construction), the test, evaluation and revision stages to produce the final product. At the needs analysis stage, it is carried out: (1) Student analysis, assessing the characteristics of student abilities; (2) Analysis of lecturers, reviewing the learning that is usually applied by lecturers in class ;; (3) Analysis of the curriculum applicable in the study program, used to select and arrange material systematically; (4) Task analysis, used to identify the main skills that will be developed in learning; and (5) Analysis of environmental demands, used to convert competencies from the results of material analysis and task analysis into basic competency competencies that must be achieved by students. The research procedure can be illustrated in Figure 1 below.

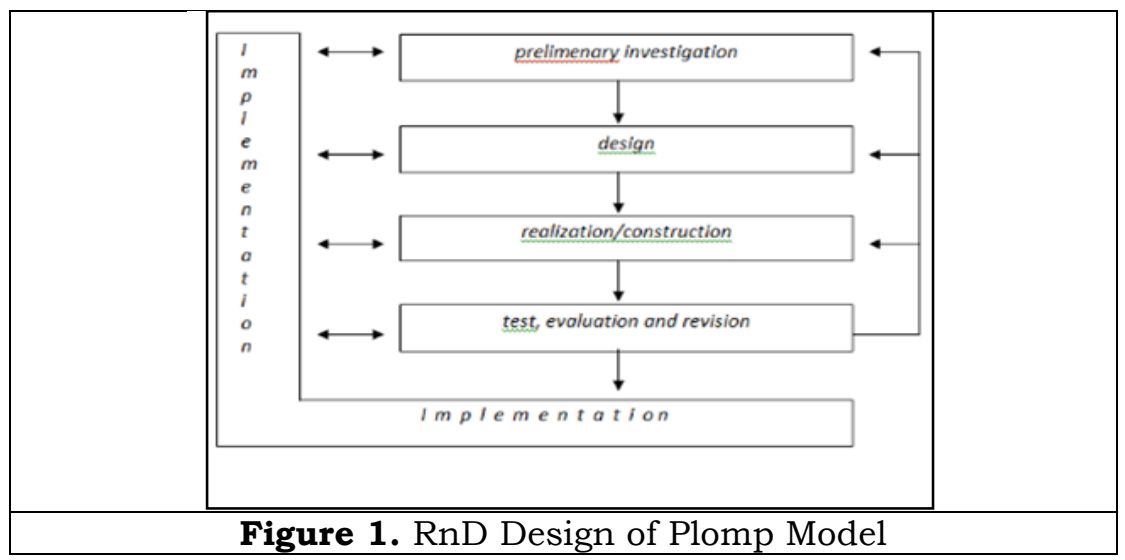

IJEI, Vol. 1, No. 1, April 2020, 29-40 
At the stage of designing the learning model design is done: (1) Preparation of the learning plan; (2) Selection of instructional media; (3) the choice of learning model format, and (4) the initial design of the learning model.

Product Quality Criteria refer to the material and multimedia aspects with indicators which can be seen in Table 1 .

Table 1. Indicators Designed for Content Validators

\begin{tabular}{|c|c|}
\hline Aspects & Indicators \\
\hline $\begin{array}{l}\text { Self } \\
\text { Instruction }\end{array}$ & $\begin{array}{ll}- & \text { Clarity of learning objectives } \\
- & \text { Specific learning material } \\
- & \text { Supporting examples and illustrations } \\
- & \text { clarity of learning material } \\
- & \text { Availability of practice / task questions } \\
- & \text { Contextual, Simple and communicative language } \\
- & \text { Availability of material summary learning } \\
- & \text { Availability of assessment instruments } \\
- & \text { Availability of feedback on ratings } \\
- & \text { Clarity guidance } \\
- & \text { Check the exercises } \\
- & \text { Difficulty level of the given exercises } \\
- & \text { The suitability of the exercise with the learning outcomes } \\
- & \text { Balance the proportion of practice questions with the contents of the Material } \\
- & \text { Availability of references that support learning material }\end{array}$ \\
\hline $\begin{array}{l}\text { Self } \\
\text { Contained }\end{array}$ & $\begin{array}{l}\text { - } \quad \text { Contains all learning material in accordance with Basic Competence } \\
\text { - } \quad \text { (organizational structure) content / description of material } \\
\text { - } \quad \text { Coverage (breadth and depth of material description) }\end{array}$ \\
\hline $\begin{array}{l}\text { Stand Alone } \\
\text { Adaptive } \\
\text { User } \\
\text { Friendly } \\
\end{array}$ & $\begin{array}{l}\text { - Not dependent on teaching materials / other media } \\
\text { - } \quad \text { Adjust science and technology, as well as flexible / flexible to use } \\
\quad \text { - Every instruction and information exposure is helpful and user friendly }\end{array}$ \\
\hline
\end{tabular}

At the realization stage a prototype of the learning model is developed. Then after the prototype is prepared, the results of the construction are examined again whether the supporting principles and theories have been accommodated in the learning model. In the test, evaluation and revision stages, validation activities and prototype learning model testing activities are carried out.

Furthermore, the indicator for feature validators can be seen at Table 2

Table 2. Indicators Designed for Features Validators

\begin{tabular}{|c|c|}
\hline$\overline{\text { Aspects }}$ & Indicators \\
\hline $\begin{array}{l}\text { Display } \\
\text { aspect }\end{array}$ & $\begin{array}{ll}- & \text { Clarity of program operating instructions } \\
- & \text { Clarity of study instructions } \\
- & \text { Readability in paragraph arrangement makes it easy for users to } \\
& \text { learn } \\
- & \text { Readability of the text in terms of the type of font used } \\
- & \text { Readability of text in terms of font size used } \\
- & \text { Appropriate use of color proportions } \\
- & \text { Clarity of the video display supporting material } \\
- & \text { Clarity of the picture display supporting material }\end{array}$ \\
\hline
\end{tabular}




\begin{tabular}{lll}
\hline \hline \multicolumn{1}{c}{ Aspects } & Indicators \\
\hline & - & Clarity of the button display \\
& - & Suitability of the cover design with the material \\
& - & Clarity of contrast between the text used and the background \\
Programming & - & Clarity of navigation and buttons to be found \\
aspects & - & Accuracy of button and navigation functions \\
& - & Ease of accessing the program menu (to go to the page the user \\
& & - \\
& - & Coynts) reaction speed \\
& - & Ease of Operation \\
Multimedia & - & Complete multimedia components \\
aspect & - & Presentation of caption text is presented close together and together \\
& &
\end{tabular}

\section{RESULTS AND DISCUSSION Development Concept}

The Development of Digital Module Innovation lies on two main bases namely human literacy and technology literacy (A. P. Goodwin \& R. T. Jimenez, 2019; E. J. Durden-Myers, Whitehead, M. E \& N. Pot, 2018; A. Hackett, Somerville and Margaret, 2017). The human literacy is represented by holding a Student Development Subject Course which requires educators to have the competence to observe the student's development process. Then for technology literacy is reflected in the Introduction to Biotechnology courses.

The initial stage in this development is an analysis of learning outcomes that must be owned by students in this case students through the analysis of the second semester learning plan of the course, namely the Development of Students and Introduction to Biotechnology. The next step is to determine the design of the Digital Module through Focused Group Discussion. From the results of the Focused Group Discussion carried out the following actions can be taken.

1 Development of two Digital Modules used for Student Development Subjects and Introduction to Biotechnology.

2 The innovation developed on this occasion is to compile a digital module in the form of a flipbook that can be inserted learning videos so that it does not seem rigid like modules in the form of .pdf or .djvu which cannot be inserted video. The output is a flipbook module in the form of .exe. 


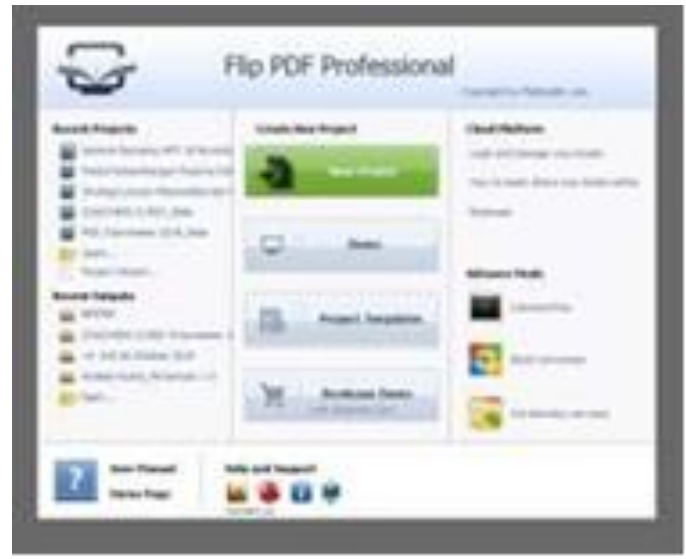

\section{Prototype Design}

Figure 2. Flipbook PDF Professional Display

By using the Flip PDF Professional application, a Digital Module has been prepared for the students' development course. The modules that have been prepared are equipped with several learning videos so that the modules are more interesting and not monotonous. Display one of the pages in the digital module for student development course or abbreviated as PPD (Perkembangan Peserta Didik) is as follows.

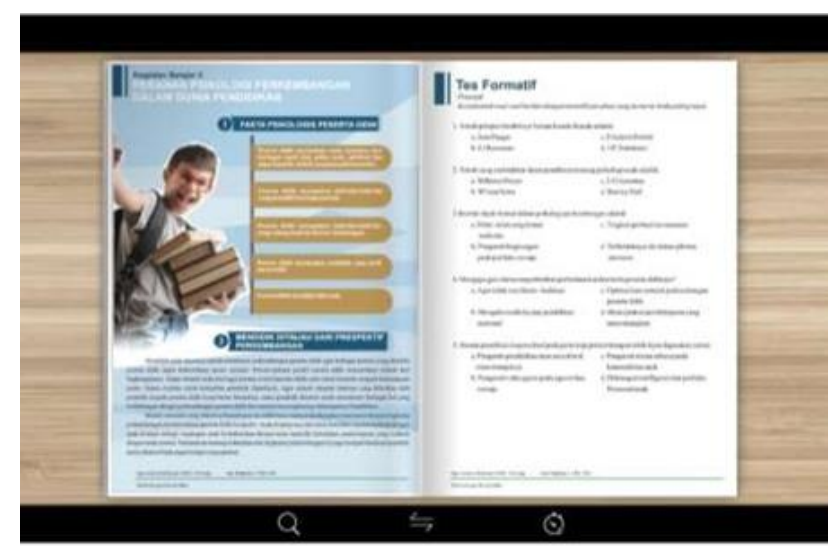

Figure 3. Digital Module of Student's Development Course

The complete version of this digital module can also be accessed on the page as shown as follow http://online.flipbuilder.com/zlwu/jbdz/.

Some documentations related to the preparation of digital modules of student's development course is as follows. 


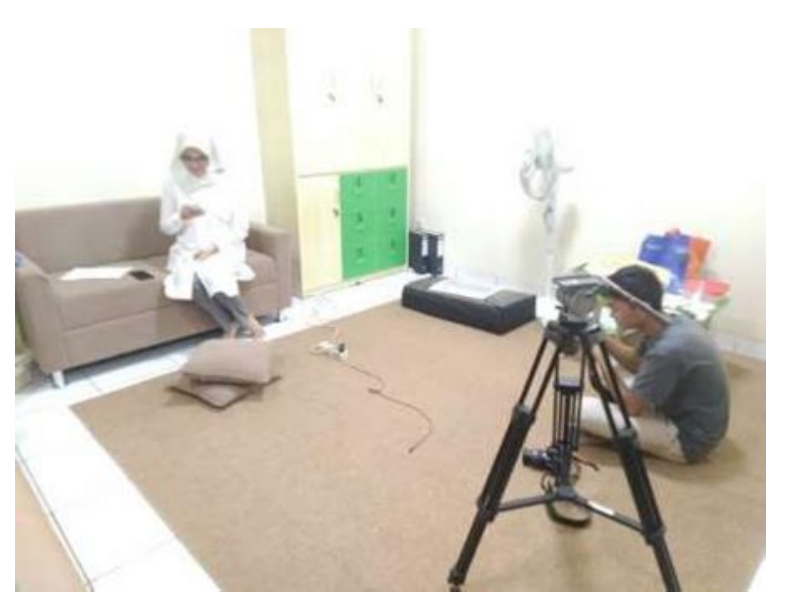

Figure 4. Taking Video For Student's Development Course Description

By using the same application, a Digital Module for Introduction to Biotechnology Course has been prepared. The modules that have been developed are as follows.

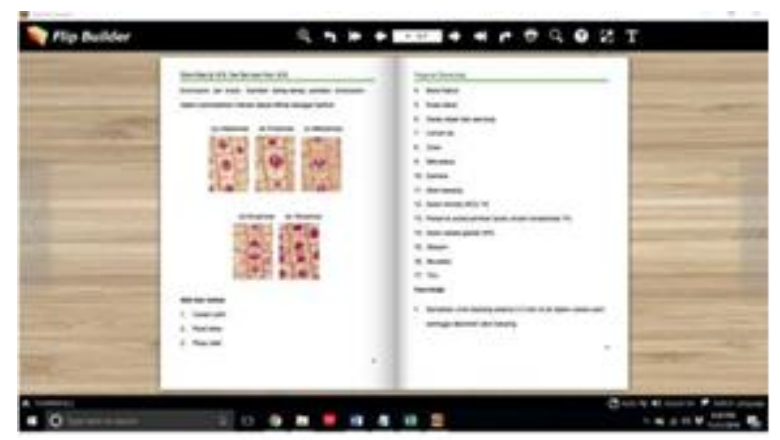

Figure 5. The Display of The Digital Module for Introduction to Biotechnology

\section{Prototype Design Installation Process on the E-Learning Website}

Two Courses that are carried out in the development of this digital module can be accessed at elearning.uad.ac.id. The link details of the two courses are described in the Table 3 as follows:

Table 3. Course on E-Learning Website

\begin{tabular}{cc}
\hline \hline \multicolumn{1}{c}{ Courses } & E-learning Link \\
\hline Student's Development Course & https://elearning.uad.ac.id/course/view.php?id=3049 \\
Introduction to Biotechnology & https://elearning.uad.ac.id/course/view.php?id=3499 \\
\hline \hline
\end{tabular}




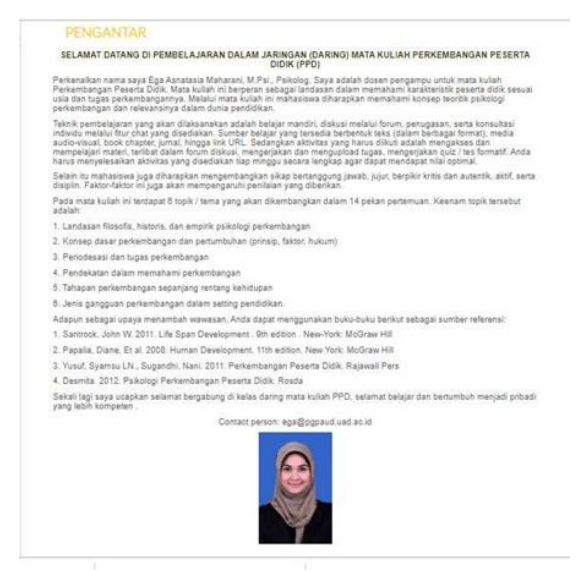

Figure 6. The Display of Student Development Course on the E-Learning Website

To maintain the quality of digital modules that are developed, as planned there needs to be a validation of experts who will assess the digital module on Student Development and Introduction to Biotechnology.

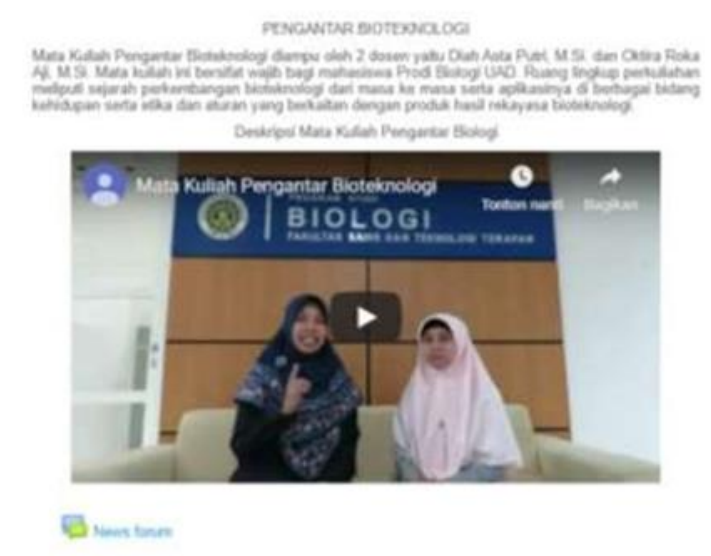

Figure 7. The Introduction to Biotechnology Course on the E-Learning Website

The Validation Experts who will be involved in the assessment process consist of two types of validators.

1 Validator in the field of digital module features with Educational Technology background

2 Scientific content validator with Psychology background for the Digital Module for Student Development and with Biology background for Digital Module for Student Development. 


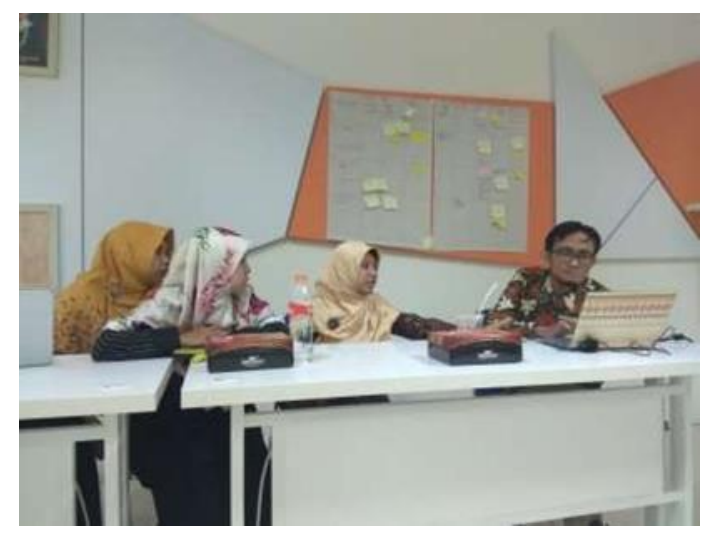

Figure 8. Validator Reviews the Prototypes

The results of validation in the Focused Group Discussion conducted, there are some input and suggestions from the validator shown in Table 4 as follows.

Table 4. Validator Comments and Suggestions

\begin{tabular}{ll}
\hline \hline \multicolumn{1}{c}{ Courses } & \multicolumn{1}{c}{ Suggestions } \\
\hline $\begin{array}{l}\text { Introduction to } \\
\text { Biotechnology }\end{array}$ & $\begin{array}{l}\text { The module is good, the source has referred to the results of biotechnology } \\
\text { research, it has also been equipped with pictures and videos so that it is easy } \\
\text { to understand the material. }\end{array}$ \\
& Conclusion: the module is feasible to use \\
& $\begin{array}{l}\text { Media expert advice: need to be given instructions on how to use digital } \\
\text { modules, you can add them to e-learning }\end{array}$ \\
$\begin{array}{l}\text { Student's } \\
\text { Development }\end{array}$ & $\begin{array}{l}\text { The module is good, the source has referred to the results of biotechnology } \\
\text { research, it has also been equipped with pictures and videos so that it is easy } \\
\text { to understand the material. }\end{array}$ \\
& Conclusion: the module is feasible to use \\
\hline \hline
\end{tabular}

In the Industry Revolution 4.0 Era, Indonesian human resources are currently demanded to not only have enough old literacy (reading, writing, \& mathematics) as a basic capital in social life but must have new literacy which of course must also be prepared very carefully by the institution education as a means of education for agents of change. The new literacy includes three types of literacy, namely 1) data literacy, 2) technological literacy, and 3) human literacy. Human literacy is related to communication skills, collaboration, critical thinking, creative and innovative. The details of human literacy are to have the skills:

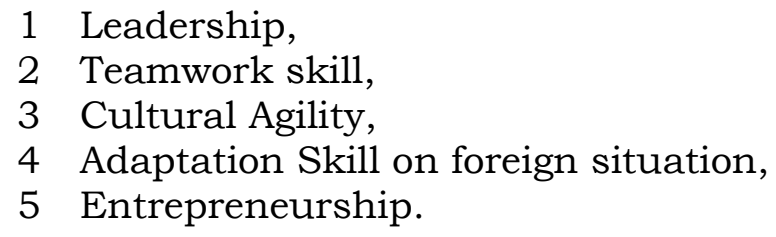

Meanwhile, for universities the literacy of data and technology can be applied through the courses offered. As for human literacy can be done through 
thematic studies across disciplines, connecting with the real world, projectbased learning. As a form of support for human literacy, the Faculty of Education and Teacher Training of Universitas Ahmad Dahlan offers compulsory courses in the form of Student Development and Educational Psychology associated with the real world and other fields of science such as Guidance and Counseling Education, Mathematics Education, Biology Education, Physics Education, Indonesian Language and Literature Education, English Language Education, Pancasila and Citizenship Education, Elementary School Teacher Education, and Early Childhood Teacher Education. Indriyanti \& Susilowati in N. Y. Indriyanti \& E. Susilowati (2010), have explained the benefits derived from learning by applying the module as follows.

1 Increase student motivation, because every time you work on college assignments that are clearly defined and in accordance with ability.

2 After the evaluation, the lecturers and students know well, which modules the students have succeeded in and which part of the module they have not succeeded.

3 Students achieve results according to their abilities.

4 Learning materials are divided more evenly in one semester

5 Education is more efficient, because learning materials are arranged according to academic levels.

The explanation above strengthens the belief of researchers that lectures with effective modules will be able to change students' conceptions towards scientific concepts, so that in turn their learning outcomes can be optimally improved both in terms of quality and quantity.

Based on the results of the needs questionnaire analysis, data obtained that the needs of students towards the development of digital modules in the PPD Subject and Introduction to Biotechnology are relatively high. Therefore, module development needs to be continued by analyzing curriculum and material and adjusting to the characteristics of students.

Digital module is a form of module digitalized and packaged more interactively M. H. Lin, H. C. Chen and K. S. Liu (2017). Digital module is a medium for independent learning because it has been equipped with instructions for self-study S. Raihan, Haryono and F. Ahmadi (2019). The digital module in this study is filled with material in the form of pdf compiled using a flipbook. This digital module also contains simulation pictures and videos that can help students understand abstract material. The effectiveness of literacyoriented teaching materials is that it can improve student learning outcomes ( $T$. W. Damayantia, Sutrisno, I. Subektic \& Z. Baridwand,2015).

Literacy that appears at the time of application of the module in the form of active questioning during learning. Students answer questions by modeling the events they experienced and those they encountered in their daily lives. Literacy activities are trained through reading habits in class and outside the classroom. Literacy is formed when students are able to apply the information they receive into action in the form of positive action. The direct impact is the increase in students' understanding of the material being studied. This literacy habit is strongly influenced by the digital module used.

Learning with digital modules has many advantages as follows: increasing student motivation, because each time doing a task that is clearly defined and in accordance with ability; After evaluating, the lecturer and student know which part the student has succeeded or unsuccessful, and also with the use of this module the student achieves results according to his ability because in essence students have the ability to work alone and are more responsible for their actions (L. Wita Harahap \& E. Surya, 2019; F. Ferdianto \& N. Alfiani, 2019).

This is in line with opinions of D. Purnomo, M. Indrowati and P. Karyanto, 
(2013); A. N. R. Siadi (2013); M. W. Setiyadi (2017), which reveal the benefits of learning to use modules, including: student motivation to do assignments according to their abilities; after the lesson is finished, the teacher and students know the level of success; students achieve results that match their abilities; the learning load is divided more evenly throughout the semester; and more efficient education. Learning to use modules has many benefits, students can be responsible for their own learning activities, learning with modules highly values individual differences, so students can learn according to their ability levels, so learning is more effective and efficient

\section{CONCLUSION}

Based on the result of the research that has been described, it can be concluded that the researcher has succeeded in developing a digital module through the RnD stage of the Plomp model and its feasibility has been tested for learning. The implementation results on digital module of Student's Development Course (respectively, Introduction to Biotechnology Course) will be carried out in the even (respectively, odd) semester of 2019/2020 academic year by involving 2 study programs, that are, Pre-School Teacher Training and Biology department.

\section{ACKNOWLEDGEMENT}

The authors would like to thank the Director of BELMAWA KEMENRISTEKDIKTI for the funding assistance in the development of digital module innovations 2019 so that this research can be carried out well.

\section{REFERENCES}

Berg, A., Buffie, E. F., \& Zanna, L. F. (2018). Should we fear the robot revolution? (The correct answer is yes). Journal of Monetary Economics, 97, 117-148.

Damayanti, T. W., Subekti, I., \& Baridwan, Z. (2015). Trust and uncertainty orientation: An effort to create tax compliance in social psychology framework. Procedia-Social and Behavioral Sciences, 211, 938-944.

Durden-Myers, E. J., Whitehead, M. E., \& Pot, N. (2018). Physical literacy and human flourishing. Journal of Teaching in Physical Education, 37(3), 308311.

Ferdianto, F., \& Alfiani, N. (2019, October). Digital module and treffinger model: can improve mathematics ability. In Journal of Physics: Conference Series (Vol. 1360, No. 1, p. 012035). IOP Publishing.

Goodwin, A. P., \& Jiménez, R. T. (2019). Literacy and human rights. Reading Research Quarterly, 54(4), 449-450.

Gunal, M. M. (2019). Simulation and the fourth industrial revolution. In Simulation for Industry 4.0 (pp. 1-17). Springer, Cham.

Hackett, A., \& Somerville, M. (2017). Posthuman literacies: Young children moving in time, place and more-than-human worlds. Journal of Early Childhood Literacy, 17(3), 374-391.

Harahap, L. W., \& Surya, E. (2017). Development of Learning Media in Mathematics for Students with Special Needs. International Journal of Sciences: Basic and Applied Research (IJSBAR), 33(3), 1-12.

Indriyanti, N. Y., \& Susilowati, E. (2010). Pengembangan Modul. Surakarta: UNS Press.

Lin, M. H., \& Chen, H. G. (2017). A study of the effects of digital learning on learning motivation and learning outcome. Eurasia Journal of Mathematics, Science and Technology Education, 13(7), 3553-3564.

Raihan, S., Haryono, H., \& Ahmadi, F. (2018). Development of Scientific Learning E-Book Using 3D Pageflip Professional Program. Innovative Journal of Curriculum and Educational Technology, 7(1), 7-14.

Purnomo, D., Indrowati, M., \& Karyanto, P. (2013). Pengaruh Penggunaan 
Modul Hasil Penelitian Pencemaran di Sungai Pepe Surakarta sebagai Sumber Belajar Biologi Pokok Bahasan Pencemaran Lingkungan terhadap Hasil Belajar Siswa. Jurnal Pendidikan Biologi, 5(1), 59-69.

Rosyidah, A. N., Sudarmin, S. S., \& Siadi, K. K. (2013). Pengembangan Modul IPA Berbasis Etnosains Zat Aditif dalam Bahan Makanan untuk Kelas VIII SMP Negeri 1 Pegandon Kendal. Unnes Science Education Journal, 2(1).

Setiyadi, M. W. (2017). Pengembangan modul pembelajaran biologi berbasis pendekatan saintifik untuk meningkatkan hasil belajar siswa. Journal of Educational Science and Technology (EST), 3(2), 102-112. 
